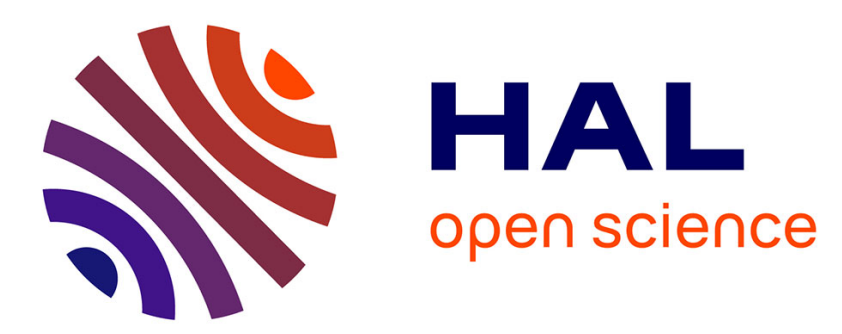

\title{
Calculating nuclear accident probabilities from empirical frequencies
}

\author{
Minh Ha-Duong, V. Journé
}

\section{To cite this version:}

Minh Ha-Duong, V. Journé. Calculating nuclear accident probabilities from empirical frequencies. Environment Systems and Decisions, 2014, 34 (2), pp.249-258. 10.1007/s10669-014-9499-0 . hal01018478v2

\section{HAL Id: hal-01018478 \\ https://hal.science/hal-01018478v2}

Submitted on 21 Jul 2014

HAL is a multi-disciplinary open access archive for the deposit and dissemination of scientific research documents, whether they are published or not. The documents may come from teaching and research institutions in France or abroad, or from public or private research centers.
L'archive ouverte pluridisciplinaire HAL, est destinée au dépôt et à la diffusion de documents scientifiques de niveau recherche, publiés ou non, émanant des établissements d'enseignement et de recherche français ou étrangers, des laboratoires publics ou privés.

\section{(1)(1) $\$(0)$}

Distributed under a Creative Commons Attribution - NonCommercial - ShareAlikel 4.0 


\title{
CALCULATING NUCLEAR ACCIDENT PROBABILITIES FROM EMPIRICAL FREQUENCIES
}

\author{
Minh Ha-Duong et Venance Journé ${ }^{1}$
}

\author{
2014-04-10
}

\begin{abstract}
Summary
Since there is no authoritative, comprehensive and public historical record of nuclear power plant accidents, we reconstructed a nuclear accident dataset from peer-reviewed and other literature. We found that, in a sample of five random years, the worldwide historical frequency of a nuclear major accident, defined as an INES level 7 event, is $14 \%$. This value is $67 \%$ to have at least one nuclear accident rated at level $\geq 4$ on the INES scale. These numbers are subject to uncertainties because the fuzziness of the definition of a nuclear accident.
\end{abstract}

\section{Résumé}

En l'absence d'une liste d'accidents nucléaires de référence, exhaustive et publique, nous avons reconstruit l'historique des accidents nucléaires dans les centrales électriques à partir de la littérature scientifique et de diverses sources publiques. Dans un échantillon de cinq années aléatoires, la probabilité d'avoir dans le monde un accident nucléaire majeur (niveau INES 7) est de 14\%. Celle d'avoir au moins un accident nucléaire (niveau INES $\geq 4$ ) est de $67 \%$. Ces chiffres sont entachés d'incertitude à cause du caractère flou dans la définition d'un accident nucléaire.

\section{Introduction}

The major accident that occurred in Fukushima on 11 March 2011 led to a renewed scientific interest in assessing nuclear risks. In the press, there has been a number of declarations such as Laponche et al. (2011) who claimed that the probability of a serious nuclear accident in the next thirty years was a "statistical certainty" for the European Union. Moreover countries such as Austria, China, Finland, France, Germany, India and Italy have responded with the adoption of very diverse nuclear safety and energy policies. Considering the policy importance of this issue, we recompute these estimates constructing our own data set and using a different method. 
Risk has two dimensions: the probability of an accident and the magnitude of its consequences. This paper deals with the first dimension of risk, the probability. The causes that might result in a serious nuclear accident are manifold and they include but are not limited to: design errors, construction problems, material or hardware deficiencies, internal events such as pipe break or fire, external events such as a plane crash or natural hazards (earthquake, floods), and mostly human causes, such as errors in manipulation, insufficient safety information, bad knowledge of instructions. In many cases, the accidents are due to a combination of several factors.

Despite the complexity of causes, nuclear engineers and scientists have tried to estimate the probability of a nuclear accident. One commonly used method is the probabilistic risk assessment (PRA) method that computes, in a bottom-up combination, the probability of an accident as the product of the probabilities of all known different possible failures. This method allows to assess risks and identify potentials to improve safety. However, However, the PRA analysis are bound to be subject to uncertainties since they cannot be totally exhaustive and there are uncertainties in knowledge. This usually results in a small probability.

Table 1 shows how the predictions for the PRA methodology compare to the historical record. In the first column, are indicated given nuclear accident probabilities per reactor per year, denoted $\varepsilon$. The numerical objective defined for core damage frequency, as evaluated from PRA studies, range from $10^{-4}$ to $10^{-6}$ for regulators in different countries (NEA-OECD, 2012). The second column shows at the expected number of accidents in the whole history of the nuclear industry for each value of $\varepsilon$. As of end of 2012, 437 reactors were in operation worldwide, and the cumulative nuclear reactor-years of operation worldwide and including all technologies adds up to 15,080 (European Nuclear Society, 2013). These values should correspond to core damage accidents of 0,15 to 1,5 for 15,080 reactor-years $(15,080$ times $\varepsilon)$. This number is small compared to the real number of accidents. 


\begin{tabular}{llll}
\hline $\begin{array}{l}\text { Accident probability } \\
\text { per reactor per year }\end{array}$ & $\begin{array}{l}\text { Expected number of } \\
\text { accidents since } \mathbf{1 9 5 0}\end{array}$ & $\begin{array}{l}\text { Probability of at least } \\
\text { one accident in } \mathbf{5} \text { years }\end{array}$ & $\begin{array}{l}\text { Probability of at least one } \\
\text { accident in } 30 \text { years }\end{array}$ \\
$\varepsilon$ & $15080 * \varepsilon$ & $1-(1-\varepsilon)^{\wedge}\left(437^{\star} 5\right)$ & $1-(1-\varepsilon)^{\wedge}\left(437^{\star} 30\right)$ \\
\hline $10^{\wedge}-6$ & 0.015 & $0,22 \%$ & $1,30 \%$ \\
$10^{\wedge}-5$ & 0.15 & $2,16 \%$ & $12,29 \%$ \\
$10^{\wedge}-4$ & 1.5 & $19,63 \%$ & $73,05 \%$ \\
$10^{\wedge}-3$ & 15 & $88,76 \%$ & $99,9998 \%$ \\
\hline
\end{tabular}

Table 1 : Four viewpoints on accidents probability.

The probability of an accident per reactor per year (first column) remains the same along each line. The probability of seeing an accident depends on how many reactors are observed during how many years.

The third and fourth columns indicate the probabilities of having an accident in five and 30 years for 437 reactors, assuming that the reactor-year accident probability is $\varepsilon$. The number of 437 reactors corresponds approximately to the number of nuclear reactors operating in the world today.

Thus given the complexity of the overall system, and the discrepancy between the values given by PRA analyzes and the number of accidents, a holistic approach such as the use of historical frequencies is used in this study. We assess the frequency of a nuclear accident and of a major accident from past experience.

In section 2, the basis on which nuclear accidents have been selected to construct the data set is defined and the way in which the discrete INES scale does not take into account the complexities of a reality which is "fuzzy" is explained. Section 3 contains a review of some literature on nuclear accident risks with emphasis on probability estimates and nuclear accident inventories. In section 4 , the construction of the data set is described. The method and results are presented in section 5 and 6 . Section 7 concludes.

\section{INES scale and nuclear accidents}

The International Nuclear and Radiological Event Scale (INES) is a worldwide tool for communicating to the public the safety significance of nuclear and radiological events (IAEA, 2009). It was developed by the International Atomic Energy Agency (IAEA) : the IAEA statutes (article II - Objectives) states that "The Agency shall seek to accelerate and enlarge the contribution of atomic energy to peace, health and prosperity throughout the world. It shall ensure, so far as it is able, that assistance provided by it or at its request or under its supervision or control is not used in such a way as to further any military purpose" (IAEA, 2012) - and the OECD Nuclear Energy Agency - whose mission is "To assist its member countries in maintaining and further developing, through international co-operation, the scientific, technological and legal bases required 
for a safe, environmentally friendly and economical use of nuclear energy for peaceful purposes. To provide authoritative assessments and to forge common understandings on key issues as input to government decisions on nuclear energy policy and to broader OECD policy analyzes in areas such as energy and sustainable development."(NEA, 2013)

Events are classified on the scale with 7levels. For communicating to the public, distinct designations have been attributed to each level, from anomaly (level 1) to major accident (level 7): " the severity of an event could increase by about an order of magnitude for each increase in level on the scale » (IAEA, 2009).

According to the IAEA's vocabulary, any event whose severity is rated at INES level $\geq 4$ on the INES scale is an accident. Below level 4 , the event is called incident. As mentioned above and illustrated on Table 2, there are many types of accidents. The potential consequences of an accident range from those limited to the core, to those contained inside the pressure vessel, to the release of radioactivity in the environment and those affecting the population. Because of this diversity, there are several criteria to assess the severity of an accident and the INES defines a level 4 event by any of the following characteristics:

1. At least one death from radiation.

2. Minor environmental release of radioactive material unlikely to result in implementation of planned countermeasure other than local food controls.

3. Fuel melt or damage to fuel resulting in more than $0.1 \%$ release of core inventory.

4. Release of significant quantities of radioactive material within an installation with a high probability of significant public exposure.

The IAEA criteria provides the only agreed definition of a nuclear accident. However, the construction of an historical nuclear accident data set on the basis of the INES rating is an uncertain process for the following reasons:

- Back-rating: The INES scale was developed only in 1990. Many previous events are not officially rated on the scale. Unofficial ratings may be found in the literature that may not be adequately justified.

- Fuzziness: The INES scale is a communication instrument ${ }^{2}$, not a safety evaluation tool. The INES manual provides guidance for reporting the events using only a single number, but the proper definition of an accident is complex. The fuzziness of the categorization using the INES level is apparent from the above four criteria : the terms "minor", "likely", "significant" are used. It is also the case for higher levels : one of the characteristics of rating is the quantity of radioactivity released and the

\footnotetext{
${ }^{2}$ The first lines of the INES reference User's Manual (2008 edition ) state "The need for easily communicating the significance of any event ..." (Foreword, page v.) and "The International Nuclear and Radiological Event Scale is used for promptly and consistently communicating to the public the safety significance of events associated with sources of radiation." (section 1.1) http://www-pub.iaea.org/MTCD/publications/PDF/INES2009_web.pdf)
} 
boundaries between levels from 4 to 7 are set approximately to 500,5000 and 50000 tera-becquerels (IAEA, 2009, p. 17). Moreover, the quantitative variables used to rate accidents, such as the released radioactivity, cannot be always precisely estimated either.

- Heterogeneity: The difficulty to characterize precisely an accident and its consequences, and therefore the ensuing fuzziness of the INES scale, makes the historical and geographical uniformity of assessment difficult to ensure, unlike the Richter earthquake magnitude scale for example. This difficulty could be partially alleviated if there were a world entity in charge of the consistent interpretation and rating of an accident. But rating is the responsibility of the power plant owner, or of the regulation entity in certain countries such as France, which is therefore the unique source of primary information. This can lead to important differences in reporting.

- Secrecy: To be notable, an event must have caused well-attested and substantial radioactivity release and contamination. For example, an accident that occurred in September 1957 in Soviet Union has been acknowledged only decades after :the waste storage explosion at Mayak, a plutonium production reactor for nuclear weapons and nuclear fuel reprocessing plant, near Kyshtym. This accident would have been rated at level 6 on the INES scale, 15,000 square kilometers were contaminated. It was made public to the outside world by Soviet dissident Zhores Medvedev in 1976 (Medvedev, 1976). The fact that serious events are not made public may also occur in the West: on 17 December 1987, eighteen months after the Chernobyl major accident, a serious incident occurred in the Biblis power station in West Germany. It was known internationally nine months later in an expert meeting in Vienna and made public one year later in an article published by Nucleonics Week, and rated at level 1 on the INES scale (Hibbs, et al, 1988). Therefore this serious incident in a purely civilian nuclear power plant was not known to the IAEA when it occurred. These examples underline the fact that some events, which could involve important radiation contamination or potential for much more serious consequences, can be kept secret from the public.

- Dual and multiple uses: Some accidents cannot be attributed only to power production. This is the case for those occurring in nuclear reactors producing jointly isotopes and electric power. Also, research and commercial uses cannot be distinguished in the case of large-scale reactor prototypes.

- Simultaneity: Power plants usually have two or more power reactor units. In our study, several simultaneous accidents at one plant are counted as a single one, such as However, in the case of the Fukushima Daichi major accident, results will be provided counting it as one accident as well as three accidents. 


\section{Previous studies on nuclear accident frequencies}

There have been many studies on various aspects of nuclear accident frequencies and their scope is restricted to specific types or to a limited number of accidents. Assessments range from the assertion that «nuclear power plants are very robust » (World Nuclear Association, 2012) to the conclusion that " nuclear power comes with the inevitability of catastrophic accidents » (Ramana, 2011).

As stated above, Laponche and Dessus (2011) argued that nuclear accidents were statistically certain. They wrote that: "On the basis of the major accidents having occurred these last thirty years, the occurrence probability of a major accident would therefore be about $50 \%$ for France and more than $100 \%$ for European Union". Giving more details on the calculations, Ghys (2011) estimated this later probability to be about $72 \%$, based the same data (4 catastrophic core failures - 1 in Chernobyl, 3 in Fukushima - for 14000 reactor-years).

Stratton (1967) published the first seminal review of criticality accidents. This work is about a subset of nuclear accidents, and does not look at commercial nuclear power plants. It was first revised in 1989 and updated again by McLaughlin et al (2000). The 2000 edition contains 60 accidents, 19 of which are new to it.

Lochbaum (2000), for the Union of Concerned Scientists, studied the risk assessment reports published by the US Nuclear Regulatory Commission and concluded that the probability assessments were biased towards lower values by the use of many unrealistic assumptions regarding plant design, construction and operation, a very limited number of human errors.

Kastchiev et al. (2007) have studied the safety records of nuclear power plants to assess risks and possible consequences of nuclear accidents. Based on the analysis of sixteen events, they concluded that "many nuclear safety related events [...] go either entirely unnoticed by the broader public or remain significantly under-evaluated when it comes to their potential risk".

T. Cochran (2011) gave a testimony where he stated that the historical frequency of core melt accident is about 1 in 1400 reactor-years which is rather far from the probability risk assessment estimate of $2 \times 10-5$ to $1 \times 10-4$ events/reactor-year for accidents (INES level $\geq 4$ ) published in 1986 by the US Nuclear Regulatory Commission. Cochran's paper lists 12 nuclear power reactors (including Sodium Reactor Experiment) that have experienced fuel-damage or partial core-melt accidents.

Smythe (2011) proposed a new scale for the magnitude of nuclear accidents. He describes a list of 33 events in which he counts 4 events as catastrophic, leading him to conclude that "A magnitude 7 or greater accident is to be expected every $12-15$ years." 
Escobar Ranger and Lévêque (2013) have used a statistical - Poisson - model approach and performed a methodological study for the same problem, based on continuous time models and reliability theory. They found that the Fukushima major accident leads to a re-evaluation of previous risks assessments.

\section{Construction of the dataset}

The Aircraft Crashes Record Office compiles all aircraft accidents in the civilian aviation sector and makes complete and detailed statistics available to the public (ACRO, 2014). On the contrary, int he civilian nuclear energy sector, there is no world data set of nuclear accidents, and there is no way to have harmonized information on such events. The IAEA hosts a website NEWS "The Information Channel on Nuclear and radiological Events" which displays short reports of accidents as they are deposited on the website, but there is no website or directory of accidents including incident and accident statistics with detailed information on specific events. Moreover, in its disclaimer, it declares : "The IAEA makes no warranties, either express or implied, concerning the accuracy, completeness, reliability, or suitability of the information." (IAEA, 2014) Moreover, the IAEA is not legally bound to reply to all queries for information (Kastchier 2007, note page 5).

Many online sources, including the IAEA, have been consulted for this study, but with no assurance that any of them is complete. For instance, the IAEA NEWS (2012) web page states that « event reports are filed and updated by participating countries which remain responsible for all related content $»$ and does not contain an archive which is publicly available. The available information include: event description, INES rating, related technical information and press releases. We also consulted accident lists published online by Wikipedia (2012) and other sources, other databases provided by non governmental organizations, or independent researchers, some of them containing a lot of information such as Johnston's (2011) archives and Climatesceptics.org (2012).

In building this sample, the goal was to find and record all events rated at INES level $\geq 3$ which occurred at a licensed and commercially operational power plant since 1951, the start of nuclear energy for civilian purposes. Given the lack of standardized and complete world data set, the reconstructed data set suffers from the deficiencies discussed in Section 2 above. There is uncertainty on the number of events and in their rating, since the INES levels are not precise enough, including in terms on released radioactivity, and thus the frontier between accident and incidents is fuzzy.

The present study is only based on accidents with an INES level $\geq 4$. $^{3}$

\footnotetext{
${ }^{3}$ Since the limits between INES level are fuzzy, accidents rated at level $=3$ were also looked for in the research to build the dataset. This will be used, in a later study, to allow more specific tests regarding the influence on the results of this study stemming from a fuzzy frontier between different INES levels.
} 


\section{Examples of accidents related to nuclear power production}

Examples of nuclear accidents not related to electricity production, not considered in this paper
Uranium mine. Radioactive waste spill. Church Rock, USA, 1979 (no immediate direct fatality)

Fuel facility. Criticality accident with Uranium solution. Tokaimura, Japan, 1999 (2 fatalities)

Reprocessing facility. Chemical explosion following tank cooling system failure. Kychtym, Russia, 1957 $(300 \times 50 \mathrm{~km}$ area contaminated $)$

Power reactor. Partial core melt. Saint Laurent des Eaux, France, 1969. (no immediate direct fatality)
Weapons. Criticality accident with Pu metal assembly. Los Alamos, USA, 1946 (1 fatality)

Naval propulsion. K27 submarine reactor accident. Russia, 1968 (9 fatalities)

Attack. Five RPG-7 rockets fired on nuclear plant construction site. Creys-Malville, France, 1982 (minor damage)

Industrial. Lost gamma radiography source. Conceptión, Chile, 2005 (3 workers injured)

Medical. Radiotherapy overexposure. Zaragoza, Spain, 1990 (11 fatalities)

Table 2: Types of nuclear accidents. This paper only considers those involving electricity production (left column).

Several accident types are listed in Table 2. Only events of the categories described in the left column pertaining to the production of nuclear electricity are retained in the dataset. The right column shows that many other types of radiological accidents are not taken into account in the present study : military activities as well as those such as medical activities or industrial activities which cannot lead to major accidents were ignored.

For events having occurred before 1991, when the INES scale became operative, accident descriptions were used to assess a level equivalent to the INES level.

We assembled a data set of all events with an INES level $\geq 3$ in the power sector. It contains 68 records summarized in Table 3 (see annex). Excluding level 3 events, Table 4a retains all events with an INES level $\geq 4$ in all types of nuclear facilities. Excluding events in test facilities or fuel facilities, Table $4 \mathrm{~b}$ lists the 13 accidents which occurred in nuclear power plants. Those are the only ones kept for this study.

Figure 1 shows the time distribution of events by INES level and shows a decrease in the number of accidents, but the two ${ }^{4}$ major accidents occur in the later decades. Figure 2 shows the number of nuclear reactors in operation as a function of time : the number of reactors is increasing steadily until the mid 80 s, and then remains at a roughly constant level until 2012 . The comparison of those two figures shows that the bulk of accidents occurred before 1986 and that few accidents occurred when the number of reactors was at its maximum. The absolute number of accidents decreases, but the damage on environment does not decrease.

${ }^{4}$ Or four major accidents if one considers that 3 major accidents occurred in Fukushima Daichi. 


\section{Method}

An accident being defined as an event with an INES level $\geq 4$, the empirical frequency of the number of accidents over $T$ years is computed using the method described below. Over the 61 years from 1951 to 2011, there was 49 years with no accident, 11 with one accident and one year with two accidents. The number of accidents in one year is modeled as a random variable denoted $X$. This variable takes the value $0,1,2$ with a probability respectively of $49 / 61,11 / 61$ and $1 / 61$.

To consider the number of accidents in $T$ years, each year is independently drawn with re-sampling. This number is described by the random variable $Y$ defined as the sum of $T$ realizations of $X$.

The probability law of $Y$ can be computed from the probability law of $X$. This is a classical problem of probability. The combinatorial counting required here is mathematically the same as the counting involved in the expansion of polynomial. This leads to use the so-called moment-generating function of a discrete variable $X$, defined by $g_{X}(z)=\Sigma_{k} p(X=k) z^{k}$.

$$
g_{x}(z)=49 / 61+11 / 61 z+1 / 61 z^{2}
$$

The moment-generating function of $Y$ can be obtained from the momentgenerating function of $X$ by polynomial expansion:

$$
g_{Y}(z)=g_{X}(z)^{T}
$$

The coefficients of $g_{Y}(z)$ directly give the probability distribution of $Y$.

The results are shown in the Table $5 a$ for $T=5$, and in Table $5 b$ for $T=30$.

Regarding the number of major accidents, where there has been 59 years with none, and 2 years with one, the same method has been used with the generating function $59 / 61+2 / 61 \mathrm{z}$. The results are shown on the second lines on Table $5 a$ and table $5 b$.

Numerical results were verified with a different statistical method: the bootstrap method. This method relies on iterated computer simulations. It involves drawing five years randomly in $\{1951, \ldots, 2011\}$ and counting the accidents in these years. This is then repeated for 100,000 times to look at the statistical distribution of results. Since the repetition number is large enough, the statistical distribution of results is a satisfying approximation of the law of $Y$. The sample is represented in Figure 1 since it contains the number of accidents per year.

The results are shown in the Table $6 a$ for $T=5$, and in Table $6 \mathrm{~b}$ for $T=30$.

6 Results

Calculations were performed for a five-year time-span, which correspond to a typical decision-making time horizon, and for the same 30-year time-span, as used by Laponche, Dessus and Ghys. 
The results presented in Table 5 a show that for a sample of five random years, assuming that probability distribution of accidents is constant over the considered time span, the probability of having one year with one nuclear major accident (INES level $=7$ ) is $14.3 \%$, and the probability of having two major accidents is $1.0 \%$. The probability of having at least one nuclear accident (INES level $\geq 4$ ) in the same five random year sample is $66.6 \%$.

The results in Table $5 b$ show that for a sample of thirty random years the probability of drawing at least one year with a major accident is $63.2 \%$, and the probability for two or more major accidents is $25.8 \%$. These results are in agreement with the previously published studies.

Table $6 \mathrm{a}$ and Table $6 \mathrm{~b}$ show the analogous results using the bootstrap method: the absolute differences with the numbers shown Tables 5 and 6 are always less than $0,2 \%$. This validates the numerical computations of this study since the generating functions method is exact, while the bootstrap method is approximate.

Systematic errors due to the inherent ambiguities and uncertainties in the construction of the data set as discussed in Section 2 have been estimated. For example, since the study is limited to operational nuclear power plants, it does not take into account the Kychtym accident nor the Tokai-Mura criticality accident. It could be argued that one should count all accidents related to the nuclear power industry, even those that occurred in reprocessing installations. As a sensitivity analysis study, probabilities were computed including the Kyshtym event to the 13 accidents dataset. The frequency of five-year samples with no accidents drops from $33.4 \%$ to $30.2 \%$.

The main assumption underlying the computation of accident frequencies from past data is that the accident probability distribution in past years is constant. Since our sample has low statistics, our discussion on auto-correlation and trends could be only qualitative (see Hofert 2011, section 3.1 for a quantitative analysis of these questions). Auto-correlation could occur for several reasons. The occurrence of an accident in a given year may tend to decrease the risk in the following year, because of increasing awareness of plant managers and regulators worldwide. On the other hand, an accident in a reactor may increase the risk of accident in another reactor of the same plant as was the case in Fukushima.

As a sensitivity test, the same calculation was done considering what happened in Fukushima as three major accidents (INES level $=7$ ). The results are presented on table 7 .

\section{Conclusion}

Accidents at operational power plants have been considered for this study, an accident being defined as an event rated at INES level $\geq 4$, and a major accident, as an INES level 7 event. Drawing samples of five random years from the past and assuming that they are all equi-probable, the probability of having a year with 
a nuclear major accident in a five-year is $14.3 \%$. The probability of having two major accident in a five-year time span is $1.0 \%$. The probability of having at least one nuclear accident is $66.6 \%$ in a five-year sample (Table 5a). For a 30 -year sample, we found that the probability of having at least one major accident was $63.2 \%$, and a $25.8 \%$ probability of having at least two (Table $5 b$ ). Our results are in agreement with previously published studies.

Improving safety in the nuclear industry requires transparency. Since the dataset completeness is a most important parameter in risk studies, we strongly support the establishment of a complete and public international historical report of incidents and accidents worldwide with the obligation for plant owners to report. We consider that the IAEA should be the most suited organization to host such a data set since this task would very well fit in its objectives recalled above.

8 Acknowledgments

We acknowledge preliminary research by Arnaud de Myttenaere, ENSAE student intern at CIRED. We thank warmly M. V. Ramana for a careful reading of the manuscript and his valuable comments. All remaining errors are the responsibility of the authors. 


\section{Références}

Aircraft Crash Record Office, Bureau of Aircraft Accident Archives, http://www.baaaacro.com/advanced-search/. Accessed 2014-03-17.

Climatesceptics.org. Nuclear power in Europe. Unofficial online archive of all INES events as published by IAEA's website. http://www.climatesceptics.org. Accessed 2012-06-20.

Cochran, T. B. Testimony on the Fukushima Nuclear Disaster and Its Implications for U.S. Nuclear Power Reactors. Joint Hearings of the Subcommittee on Clean Air and Nuclear Safety and the Committee on Environment and Public Works. Washington, D.C.: Natural Resources Defense Council, Inc. http://www.nrdc.org/nuclear/tcochran_110412.asp. 2011.

Deutch J. (co-chair), Moniz E. (co-chair), Ansolabehere S., Driscoll M., Gray P., Holdren J., Joskow P., Lester R., and Todreas N.. The future of nuclear power, an interdisciplinary MIT study, Massachusetts Institute of Technology,

http://http://web.mit.edu/nuclearpower/. 2003

Adam Dinwoodie, Thomas Foregger. "Moment generating function of the sum of independent random variables" (version 2). PlanetMath.org. Freely available at http://planetmath.org/MomentGeneratingFunctionOfTheSumOfIndepententRandomVariab les.html. Accessed 2012-08-06

Escobar Rangel, Lina, Lévêque, François, "How Fukushima Dai-ichi core meltdown changed the probability of nuclear accidents? Safety Science 64 (2014) 90-98

European Nuclear Society, http://www.euronuclear.org/info/encyclopedia/n/nuclearpower-plant-world-wide.htm, accessed 2014-03-03

Ghys E., Accident nucléaire : une certitude statistique, un article de Libé, Images des Mathématiques, CNRS. Published online 2011-06-05,

http://images.math.cnrs.fr/Accident-nucleaire-une-certitude.html, Accessed 2012-06-20.

Mark Hibbs, Ann MacLachlan, Brian Jordan, GERMAN OFFICIALS DEFEND BIBLIS ACCIDENT PRECURSOR HANDLING, Nucleonics Week, December 8, 1988, Vol. 29, No. 49.

Hofert M. and Wûthrich M.V., Statistical Review of Nuclear Power Accidents, SSRN draft, http://ssrn.com/abstract=1923008 or doi:10.2139/ssrn.1923008, September 8th, 2011

IAEA (International Atomic Energy Agency). INES, the International Nuclear and Radiological Event Scale, Users Manual, 2008 edition. IAEA Publishing Section, 2009. http://www-pub.iaea.org/mtcd/publications/pdf/ines-2009_web.pdf

IAEA (International Atomic Energy Agency) The Statute of the IAEA, http://www.iaea.org/About/statute.html, accessed 2013-06-20.

IAEA NEWS (International Atomic Energy Agency's Nuclear Events Web-based System) About NEWS. Online at http://www-news.iaea.org/AboutNews.aspx, accessed 2012-0620.

IAEA NEWS (International Atomic Energy Agency's Nuclear Events Web-based System). Disclaimer,http://www-news.iaea.org/Disclaimer.aspx, accessed 2014-03-17

Johnson R. W., An Introduction to the Bootstrap, Teaching Statistics. Volume 23, Number 2, Summer 2001

Johnston, R. Database of Radiological Incidents and Related Events. Online database, Last modified 19 November 2011, http://www.johnstonsarchive.net/nuclear/radevents/index.html, accessed 2012-06-20.

Kastchiev G., Kromp W., Kurth S., Lochbaum D., Lyman E., Sailer M., Schneider M., Residual risk, An Account of Events in Nuclear Power Plants Since the Chernobyl Accident in 1986, http://www.greensefa.org/cms/topics/dokbin/181/181995.residual_risk@en.pdf, April 2007 
Laponche B. and Dessus B., Accident nucléaire : une certitude statistique, Libération, http://www.liberation.fr/politiques/01012341150-accident-nucleaire-une-certitudestatistique 3 june 2011.

Lelieveld J., Kunkel D., and Lawrence M.G., Global risk of radioactive fallout after major nuclear reactor accidents, Atmos. Chem. Phys., 12, 4245-4258, 201, http://www.atmoschem-phys.net/12/4245/2012/, doi:10.5194/acp-12-4245-2012

David Lochbaum. Nuclear Plants Risk Studies: Failing the grade, Union of concerned scientists report, August 2000.

http://www.ucsusa.org/nuclear_power/nuclear_power_risk/safety/nuclear-plant-risk$\underline{\text { studies.html }}$

McLaughlin, Thomas P., Shean P. Monahan, Norman L. Pruvost, Vladimir V. Frolov, Boris G. Ryazanov, and Victor I. Sviridov. A Review of Criticality Accidents. 2000

Revision. Los Alamos National Laboratory report LA-13638.

http://www.orau.org/ptp/Library/accidents/la-13638.pdf; 2000.

Medvedev, Two decades of dissidence, New Scientists, 4 November 1976,

http://books.google.ca/books?

id $=J q E h t U j q O R I C \&$ printsec=frontcover\&source=gbs_ge_summary_r\&cad $=0 \# v=0$ onepage $\& q \& \mathrm{f}=\mathrm{false}$

Medvedev, Chernobyl precursor accidents kept secret. Nucleonics Week (31 May 1990), cited by WISE - Nuclear Issues Information Service; Amsterdam.

http://www10.antenna.nl/wise/index.html?

http://www10.antenna.nl/wise/334/3342.html,1990.

Nuclear Energy Agency (NEA - OECD) webpage, http://www.oecd-nea.org/nea/ accessed 2013-08-20.

Nuclear Energy Agency (NEA - OECD) Use and Development of Probabilistic Safety Assessment, An Overview of the Situation at the end of 2010, December 2012.

Ramana M. V., Beyond our imagination: Fukushima and the problem of assessing risk, Bulletin of the atomic scientists, 19 April 2011 http://thebulletin.org/web-

edition/features/beyond-our-imagination-fukushima-and-the-problem-of-assessing-risk.

David Smythe . An objective nuclear accident magnitude scale for quantification of severe and catastrophic events. Physics Today: Points of View.

http://www.physicstoday.org/daily_edition/points_of view/an_objective_nuclear_accident magnitude_scale for_quantification_of severe_and_catastrophic events December 12, 2011

Stratton, William. R., and David R. Smith. A Review of Criticality Accidents. Lawrence Livermore National Laboratory report LA-3611. 112 pages. http://lib-www.lanl.gov/cgibin/getfile?00314607.pdf. 1967

US NRC (United States Nuclear Regulatory Commission), Office of Public Affairs. Fact Sheet on Probabilistic Risk Assessment. Institutional web page. Published online at http://www.nrc.gov/reading-rm/doc-collections/fact-sheets/probabilistic-risk-asses.htmlob. October 2007. Page Last Reviewed/Updated Friday, February 04, 2011. Accessed 201206-20

Wikipedia authors. Liste des accidents nucléaires. Online http://fr.wikipedia.org/wiki/Liste des_accidents_nucl\%C3\%A9aires. . Accessed 2012-0620

World Nuclear Association, Safety of Nuclear Power Reactors, Online at http://www.world-nuclear.org/info/inf06.html, updated 2012-05-31, Accessed 2012-06-20 


\begin{tabular}{|c|c|c|c|c|c|c|c|}
\hline INES level & NA & 3 & 4 & 5 & 6 & 7 & Total \\
\hline All facility types, all years & 22 & 17 & 22 & 4 & 1 & 2 & 68 \\
\hline Only power reactors, all years & 16 & 14 & 9 & 2 & 0 & 2 & 43 \\
\hline Other facility types, all years & 6 & 3 & 13 & 2 & 1 & 0 & 25 \\
\hline Only 1991-2011, all facility types & 4 & 17 & 2 & 0 & 0 & 1 & 24 \\
\hline
\end{tabular}

Table 3: Summary of the HJ 20120608 dataset of nuclear accidents. INES levels for pre-1991 events assessed by the author's.

\begin{tabular}{|c|c|c|c|c|c|}
\hline LOCATION & COUNTRY & FACILITY & REACTOR & TYPE & DESCRIPTION \\
\hline 12/12/52 Chalk river & Canada & Test reactor & NRX & & Core damage partial loss of coolant $\mathrm{H} 2$ explosion radioactivity release \\
\hline 29/11/55 Idaho Falls & USA & Test reactor & EBR-1 & & fast neutron reactor partial (approx half) core melt - no exposure \\
\hline 29/09/57 Kyshtym & Russia & Waste storage & & & Chemical explosion following tank cooling system failure \\
\hline 24/05/58 Chalk river & Canada & Test reactor & NRU & & Fuel rupture and fire during unloading \\
\hline 26/07/59 Santa Susana Field Lab. & USA & Test reactor & SRE & & Power excursion + approx $1 / 3$ fuel melt + radioactivity release \\
\hline 03/04/60 Waltz Mill & USA & Test reactor & & & Core melt accident ( 1 fuel element) \\
\hline 03/01/61 Idaho Falls & USA & Test reactor & SL-1 & & Main control rod manual removal + steam explosion -3 fatalities \\
\hline 24/07/64 Rhode Island & USA & Fuel fabrication & & & Criticality accident with Uranyl nitrate solution \\
\hline 21/01/69 Lucens & Switzerland & Test reactor & & & Coolant loss + power excursion and explosion. Radioactivity contained by cavem \\
\hline 17/10/69 Saint Laurent & France & Power reactor & Unit A1 & UNGG & Partial (approx $50 \mathrm{~kg} \mathrm{U}$ ) core melt during loading \\
\hline 26/05/71 Moscow & Russia & Test facility & SF-3 & & Kurchatov Institute SF-3. Fuel rods fall out of support plate - criticality - 2 fatalities \\
\hline 26/09/73 Windscale & UK & Reprocessing & Shop B 204 & & Gas leakage inside plant, Ruthenium 106 contamination, 35 workers injured \\
\hline 06/02/74 Leningrad & Russia & Power reactor & Unit 1 & RBMK-1000 & Secondary circuit rupture - 3 fatalities \\
\hline 30/11/75 Leningrad & Russia & Power reactor & Unit 1 & RBMK-1000 & Power excursion + partial core melt + atmospheric release \\
\hline 01/01/77 Beloyarsk & USSR & Power reactor & ABM-200 & early RBMK & Unit 2 - half core melt \\
\hline 26/04/86 Tchernobyl & Ukraine & Power reactor & Unit 4 & RBMK-1000 & Criticality accident + fire + steam explosion \\
\hline 24/11/89 Greifswlad & Germany & Power reactor & Unit 5 & VVER & Near core melt - 10 fuel elements damaged \\
\hline 06/04/93 Tomsk & Russia & Reprocessing & & & Explosive mechanical failure in a stainless steel reaction vessel \\
\hline 30/09/99 Tokimura & Japan & Fuel fabrication & & & Criticality accident with U solution at conversion test building \\
\hline 12/04/11 Fukushima daichi & Japan & Power reactor & Units 123 & BWR & Multiple core damage by loss of all cooling function \\
\hline
\end{tabular}

Table 4a: Subset list of civilian nuclear accidents with INES $\geq 4$.

\begin{tabular}{|c|c|c|c|c|c|}
\hline Date & City & Country & Reactor & INES & Description \\
\hline 1966-10-05 & Newport & USA & Unit 1 & 4 & Two fuel assemblies out of 105 melted \\
\hline $1967-05-01$ & Chapelcross & UK & Unit 2 & 4 & Fuel element melt and fire in part of core \\
\hline $1969-10-17$ & Saint Laurent & France & Unit 1 & 4 & Partial (approx $50 \mathrm{~kg} U$ ) core melt during loading \\
\hline $1974-02-06$ & Leningrad & Russia & Unit 1 & 4 & Secondary circuit rupture - 3 fatalities \\
\hline $1975-11-30$ & Leningrad & Russia & Unit 1 & 4 & $\begin{array}{l}\text { Power excursion + partial core melt }+ \text { atmospheric } \\
\text { release }\end{array}$ \\
\hline $1977-01-01$ & Beloyarsk & USSR & ABM-200 & 5 & Unit 2 - half core melt \\
\hline $1977-02-22$ & Jaslovske Bohunice & Slovakia & A1 & 4 & $\begin{array}{l}\text { Refueling accident + corrosion + primary and } \\
\text { secondary circuits contamination }\end{array}$ \\
\hline 1979-01-02 & Three Mile Island & USA & Unit 2 & 5 & Reactor core melt \\
\hline $1980-03-13$ & Saint Laurent & France & Unit 2 & 4 & Partial (approx 20kg U) core melt \\
\hline 1982-09-09 & Tchernobyl & Ukraine & Unit 1 & 4 & $\begin{array}{l}\text { Partial core melt - fuel assembly channel } 62-44 \\
\text { destroyed }\end{array}$ \\
\hline $1986-04-26$ & Tchernobyl & Ukraine & Unit 4 & 7 & Criticality accident + fire + steam explosion \\
\hline $1989-11-24$ & Greifswald & Germany & Unit 5 & 4 & Near core melt - 10 fuel elements damaged \\
\hline 2011-04-12 & Fukushima daichi & Japan & Units 123 & 7 & Multiple core damage by loss of all cooling function \\
\hline
\end{tabular}

Table 4b: Subset list of the 13 accidents in civilian nuclear power reactors with an INES level $\geq 4$ 
Historical dataset of nuclear accidents (HJ-20130724)

- Power plant o Other facility type

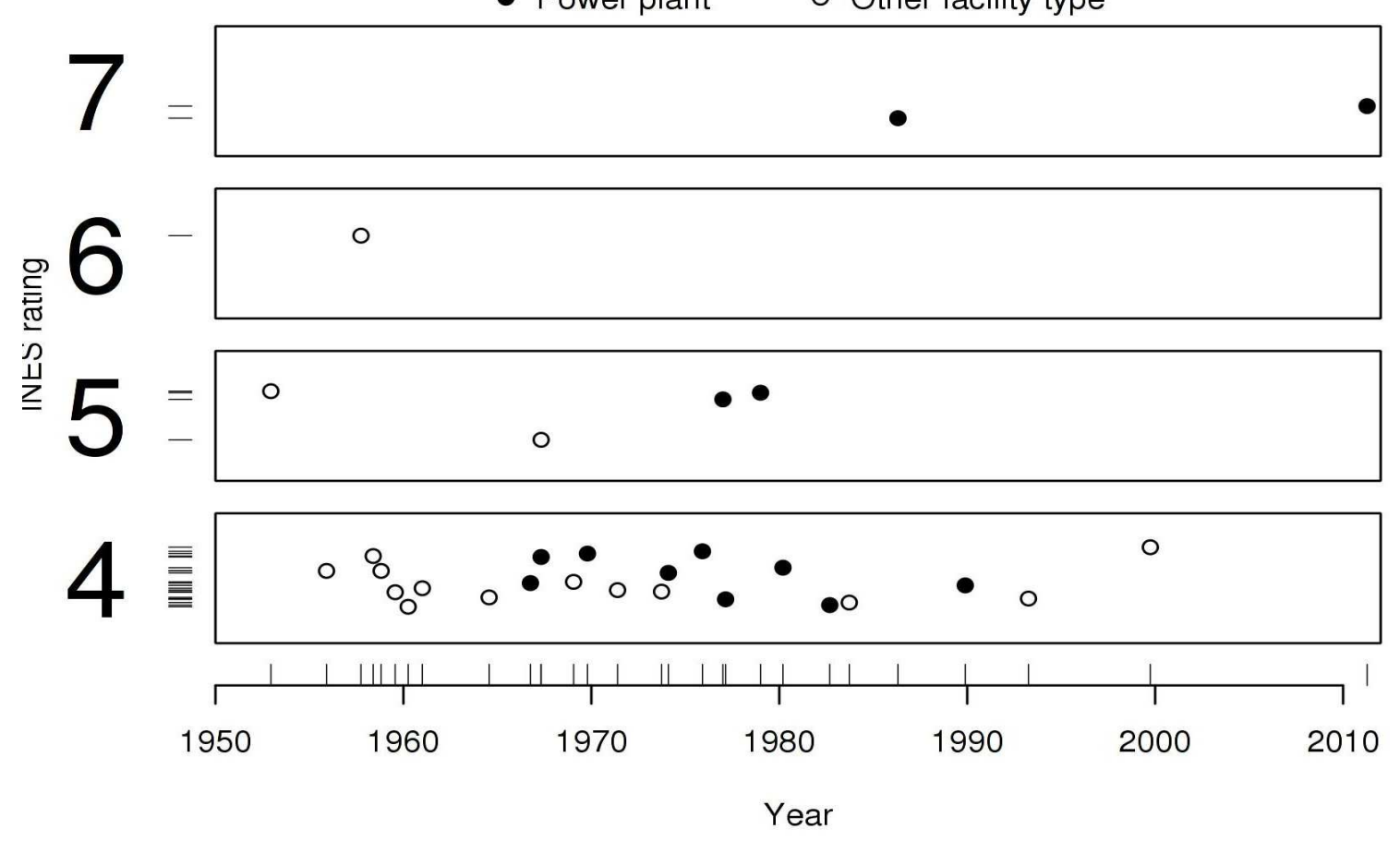

Commercial nuclear power reactors in operation

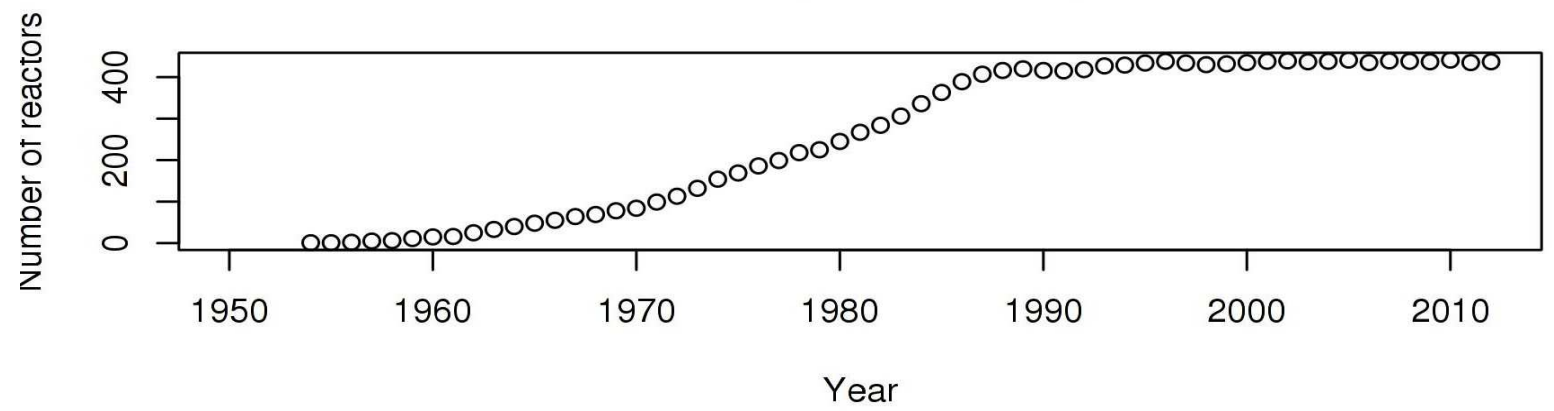

Figure 1 (top) : Chronology of accidents in this study's dataset of civilian nuclear accidents with INES level $\geq 4$ for all facilities

Figure 2 (bottom) : number of nuclear power reactors in operation, 19542012 (Source: IAEA, Nuclear power reactors in the world, 2013 edition) 


\begin{tabular}{lllll}
\hline Severity of events & $\mathbf{P}\left(\boldsymbol{N}_{i}=\mathbf{0}\right)$ & $\mathbf{P}\left(\boldsymbol{N}_{\boldsymbol{i}}=\mathbf{1}\right)$ & $\mathbf{P}\left(\boldsymbol{N}_{\boldsymbol{i}}=\mathbf{2}\right)$ & $\mathbf{P}\left(\boldsymbol{N}_{i} \geq \mathbf{3}\right)$ \\
\hline Accident (INES $\geq 4)$ & $33.4 \%$ & $37.5 \%$ & $20.3 \%$ & $8.7 \%$ \\
Major Accident $($ INES $=7)$ & $84.6 \%$ & $14.3 \%$ & $1.0 \%$ & $<0.1 \%$ \\
\hline
\end{tabular}

Table 5a

\begin{tabular}{|c|c|c|c|c|c|c|c|c|c|c|}
\hline Severity of events & $\mathrm{P}\left(N_{i}=0\right)$ & $\mathrm{P}\left(N_{i}=1\right)$ & $\mathrm{P}\left(N_{i}=2\right)$ & $\mathrm{P}\left(N_{i}=3\right)$ & $\mathrm{P}\left(N_{i}=4\right)$ & $\mathrm{P}\left(N_{i}=5\right)$ & $\mathrm{P}\left(N_{i}=6\right)$ & $\mathrm{P}\left(N_{i}=7\right)$ & $\mathrm{P}\left(N_{i}=8\right)$ & $\mathrm{P}\left(N_{i} \geq 9\right)$ \\
\hline \multirow[t]{2}{*}{ Accident (INES $\geq 4$ ) } & $0.1 \%$ & $0.9 \%$ & $3.2 \%$ & $7.0 \%$ & $11.5 \%$ & $15.1 \%$ & $16.3 \%$ & $15.0 \%$ & $11.9 \%$ & $19.0 \%$ \\
\hline & $\mathrm{P}\left(N_{i}=0\right)$ & $\mathrm{P}\left(N_{i}=1\right)$ & $\mathrm{P}\left(N_{i}=2\right)$ & $\mathrm{P}\left(N_{i}=3\right)$ & $\mathrm{P}\left(N_{i} \geq 4\right)$ & & & & & \\
\hline $\begin{array}{l}\text { Major Accident } \\
\text { (INES=7) }\end{array}$ & $36.8 \%$ & $37.4 \%$ & $18.4 \%$ & $5.8 \%$ & $1.6 \%$ & & & & & \\
\hline
\end{tabular}

\section{Table $5 b$}

Table 5 : probabilities of nuclear accident or major accident worldwide in 5-year (table 5a) and 30-year (table 5b)

\begin{tabular}{lllll}
\hline Severity of events & $\mathbf{P}\left(\boldsymbol{N}_{\boldsymbol{i}}=\mathbf{0}\right)$ & $\mathbf{P}\left(\boldsymbol{N}_{\boldsymbol{i}}=\mathbf{1 )}\right.$ & $\mathbf{P}\left(\boldsymbol{N}_{\boldsymbol{i}}=\mathbf{2}\right)$ & $\mathbf{P}\left(\boldsymbol{N}_{\boldsymbol{i}} \geq \mathbf{3}\right)$ \\
\hline Accident (INES $\geq 4)$ & $33.6 \%$ & $37.9 \%$ & $19.9 \%$ & $8.5 \%$ \\
Major Accident $($ INES $=7)$ & $84.5 \%$ & $14.4 \%$ & $1.0 \%$ & $<0.1 \%$ \\
\hline
\end{tabular}

\section{Table 6a}

\begin{tabular}{|c|c|c|c|c|c|c|c|c|c|c|}
\hline Severity of events & $\mathrm{P}\left(N_{i}=0\right)$ & $\mathrm{P}\left(N_{i}=1\right)$ & $\mathrm{P}\left(N_{i}=2\right)$ & $\mathrm{P}\left(N_{i}=3\right)$ & $\mathrm{P}\left(N_{i}=4\right)$ & $\mathrm{P}\left(N_{i}=5\right)$ & $\mathrm{P}\left(N_{i}=6\right)$ & $\mathrm{P}\left(N_{i}=7\right)$ & $\mathrm{P}\left(N_{i}=8\right)$ & $\mathrm{P}\left(N_{i} \geq 9\right)$ \\
\hline \multirow[t]{2}{*}{ Accident (INES $\geq 4$ ) } & $0.1 \%$ & $0.9 \%$ & $3.1 \%$ & $7.1 \%$ & $11.5 \%$ & $15.1 \%$ & $16.4 \%$ & $14.8 \%$ & $11.8 \%$ & $19.2 \%$ \\
\hline & $\mathrm{P}\left(N_{i}=0\right)$ & $\mathrm{P}\left(N_{i}=1\right)$ & $\mathrm{P}\left(N_{i}=2\right)$ & $\mathrm{P}\left(N_{i}=3\right)$ & $\mathrm{P}\left(N_{i} \geq 4\right)$ & & & & & \\
\hline $\begin{array}{l}\text { Major Accident } \\
\text { (INES=7) }\end{array}$ & $37.0 \%$ & $37.2 \%$ & $18.5 \%$ & $5.7 \%$ & $1.6 \%$ & & & & & \\
\hline
\end{tabular}

\section{Table $6 b$}

Table 6 : probabilities of nuclear accident or major accident worldwide in 5-year (table 6a) 30-year (table 6b) using the bootstrap method

\begin{tabular}{lllll}
\hline Severity of events & $\mathbf{P}\left(\boldsymbol{N}_{i}=\mathbf{0}\right)$ & $\mathbf{P}\left(\boldsymbol{N}_{i}=\mathbf{1}\right)$ & $\mathbf{P}\left(\boldsymbol{N}_{\boldsymbol{i}}=\mathbf{2}\right)$ & $\mathbf{P}\left(\boldsymbol{N}_{i} \geq \mathbf{3}\right)$ \\
\hline Accident (INES $\geq 4)$ & $33.4 \%$ & $34.1 \%$ & $17.3 \%$ & $15.0 \%$ \\
Major Accident (INES=7) & $84.6 \%$ & $7.2 \%$ & $0.2 \%$ & $8.0 \%$ \\
\hline \multicolumn{5}{c}{ Table $7 \mathbf{a}$} \\
\hline Severity of events & $\mathbf{P}\left(\boldsymbol{N}_{\boldsymbol{i}}=\mathbf{0}\right)$ & $\mathbf{P}\left(\boldsymbol{N}_{\boldsymbol{i}}=\mathbf{1}\right)$ & $\mathbf{P}\left(\boldsymbol{N}_{\boldsymbol{i}}=\mathbf{2}\right)$ & $\mathbf{P}\left(\boldsymbol{N}_{i} \geq \mathbf{3}\right)$ \\
\hline Accident (INES $\geq 4)$ & $33.3 \%$ & $34.3 \%$ & $17.5 \%$ & $15.1 \%$ \\
Major Accident (INES=7) & $84.7 \%$ & $7.1 \%$ & $0,2 \%$ & $7.9 \%$ \\
\hline
\end{tabular}

Table 7b

Table 7 : probabilities of nuclear accident or major accident worldwide in 5-year (table 7a) and using the bootstrap method (table 7b) counting the Fukushima event as 3 major accidents 